\title{
DHH wt Allele
}

National Cancer Institute

\section{Source}

National Cancer Institute. DHH wt Allele. NCI Thesaurus. Code C106443.

Human DHH wild-type allele is located in the vicinity of $12 \mathrm{q} 13.12$ and is approximately 5 $\mathrm{kb}$ in length. This allele, which encodes desert hedgehog protein, is involved in the regulation of both male gonadal differentiation and perineurial development. Mutations in this gene are associated with both 46XY partial gonadal dysgenesis, with minifascicular neuropathy, and 46XY sex reversal 7. 